\title{
Developing Competence in Basic Writing Skills: Perceptions of EFL Undergraduates
}

\author{
George Mathew Nalliveettil*, Abdullah Mahasneh
}

Aljouf University, Saudi Arabia

Corresponding Author: George Mathew Nalliveettil, E-mail: ngeorgemathew09@gmail.com

\section{ARTICLE INFO}

\section{Article history}

Received: June 08, 2017

Accepted: August 22, 2017

Published: December 01, 2017

Volume: 6 Issue: 7

Special Issue on Language \& Literature Advance access: September 2017

Conflicts of interest: None Funding: None

\begin{abstract}
English language course materials in EFL contexts are tailored to enhance the proficiency levels of receptive and productive skills of undergraduates. These course materials are designed in the form of worksheets to fulfil the aims and objectives of communicative/task based syllabus. During the process of completing these tasks/activities, students are expected to actively engage in writing words and meaningful sentences. In order to understand the effectiveness of their writing skills, the researchers administered a 30-item questionnaire to EFL undergraduates studying at Aljouf University, Saudi Arabia. This study focused on eliciting the perceptions of EFL undergraduates on various aspects related to writing proficiency. A total of 52 male students participated in responding to the questionnaire. The findings of our study reveal that translating strategies often impede progress in the writing skills development.
\end{abstract}

Key words: Writing, Skills, EFL, Tasks, Teaching, Learning

\section{RATIONALE}

The ever-increasing need to enhance academic writing skills in EFL undergraduate contexts requires researchers to uncover the perceptions of those active and passive learners who regularly interact with their course materials. The perceptions that these learners carry along with them during the on-campus and off-campus writing activities influence their motivational levels. Whenever, these EFL undergraduates are assigned tasks and activities, their past, and current experiences of writing English language words and sentences either motivates or demotivates their approach to a given writing task or activity. An understanding of their perceptions on a broad range of writing tasks or activities gives necessary guidance to the language teachers to take necessary steps and deliver the needed input in EFL contexts. Hazarika and Taj (2016) points out that though all the skills are equally important in language, writing is considered to be used more in academic disciplines and in the classroom teachers can use it as a means to examine the performance or achievement levels of students in their concerned fields of study. The prominence of writing skills in everyday classroom activities necessitated the researchers to undertake this study to elicit EFL students' self-perceptions that hinder or shape their attitudes toward a variety of academic writing activities. It is a requirement for all the first level of arts and science students pursuing undergraduate courses at Aljouf University to pass the courses offered in English writing skills at the entry level of college education. Also, students specializing in English language courses are required to have adequate proficiency to construct appropriate syntactic structures as well as making it semantically relevant to a given writing task. Everyday classroom writing activities include - note-taking, note-making, paragraph writing, information-gap activities, integrated language skills activities and periodical writing tests. The learning outcomes in each of these activities are expected to improve their competency levels in sentence construction skills as well as make them competent to function in different situations. However, the effectiveness of their writing skills is also dependent on the proficiency levels they have acquired during their school education. The success and failures that they have experienced while writing sentences and spellings of different English words during the school education, often influence their attitudes towards writing skills at the college education. The process and product approaches followed in course materials can make the writing activities more challenging to the EFL students. Mohite (2014) is of the opinion that competent L2 writers can take charge of their L2 writing because they use a variety of L2 writing strategies. Taking charge of L2 writing skills require EFL students to activate their schemata and apply higher cognitive skills to make meaningful sentences. The phobia of making grammatical errors often hinders their progress leading to a written discourse that is illogical to a given writing activity. These phobias carried over from their past L2 writing experiences remain as an obstacle to their academic success. The constraints of time often make the EFL teachers focus more on course materials and ignore the perceptions that these students carry as they progress from beginning to the higher levels of undergraduate education. The present research intends to uncover the perceptions of EFL undergraduates and provide rich data for the EFL language teacher educators and curriculum designers to make 
the teaching-learning of writing skills more productive in EFL classrooms.

\section{REVIEW OF LITERATURE}

The debate of the LSRW skills as to which skills are superior to other skills often makes a linguist perplexed. Most of the researchers agree that receptive and productive skills are inter-related, while on the other hand language teachers though they are aware of the inter-relatedness of LSRW skills are still struggling to improve the proficiency levels of their students. Writing is an extended activity of listening and speaking, so more opportunities must be provided to build, extend and refine oral language to improve written output in EFL/ESL situations (Hoch, n.d.). An observation of EFL teaching-learning contexts reveals that the major part of students' academic success in EFL contexts are measured in their ability to produce written scripts of what they have read and understood via summative and formative assessments. While the researchers in the field of English language skills give umpteen number of reasons to justify their stance, highlighting language learning theories and findings of various studies conducted in the field, thus contributing to the area of second language research. Also, this debate resulted in many researchers to produce volumes of papers on the importance of each of the language skills.

\section{WRITING SKILLS IN EFL CONTEXT}

In most of the EFL situations, non-native speakers of English begin to learn to write English words and sentences much later as compared to their L1 writing skills. Due to its relevance as a medium of communication in the local context, L1 writing skills often gain more prominence during the early stages of school education. "Even in these days of the internet and other technologies, written communication in English is still an asset for the aspiring student." (Abraham 2015, P.115). Despite the best efforts of the EFL language educators to enhance the writing skills at secondary and post-secondary education, it remains unfulfilled and thereby remaining as a challenge at the EFL undergraduate level. The non-native English learners do require constant opportunities for improvement at every stage of learning how to write.(Deshpande 2014, p.68). Students who have poor proficiency levels in writing skills may lag behind in both their academic and career prospects (Almubark 2016, p.11). Researchers are of the opinion that the ability to write is usually learned or culturally transmitted as a set of practices in formal teaching-learning contexts but not a naturally acquired skill (Myles 2002). Since writing is not a naturally acquired skill, the EFL learners have to take efforts to learn the spellings, word structures, sentence structures and higher-order skills to communicate the intended message successfully in different situations and contexts. According to Craig (2013), "ideally, the progression of writing skill begins early in university education and develop as students become more proficient in academic writing" (P.149). Kroll $(1990: 2)$ is of the opinion that language teachers have to realize that the students who are involved in mastering L2 writing skills are often confronted both by the complexities in learning a second language and the influences of first language literacy skills which may either hinder or facilitate the acquisition of second language proficiency. In the context of Arabic medium learners, the initial setbacks and confusions in constructing simple sentence structures due to semantic and syntactic variations of L1 and L2, impede their progress in writing skills. As these EFL students progress from their school education to undergraduate, most of them experience high levels of literacies in L1 and lower levels of L2 English academic literacies (Cai 2013:5). Moreover, the need for written English does not arise as frequently as that of Arabic, which, in turn, leads to a limited use of written communication in L2. Lamtara (2016:156) points out that in EFL contexts learners and teachers perceive writing skills with some level of uncertainty because the learners are expected to express their ideas in well-structured pieces of writing while the teachers lack adequate instructional techniques to engage and motivate the learners towards the writing skills. Due to their poor proficiency levels, ESL/EFL beginners may find it difficult to recognize their own errors and so teachers can develop a self-assessment checklist to guide these learners to monitor their writing skills (Hoch, n.d.). Many learners are not interested to actively involve in writing activities due to unsatisfactory results and achievements (Westwood,2004). Another constraint for many native students while writing spellings of English words is the interference of L1, wherein, they tend to transfer the orthographic conventions of Arabic and thereby make errors (Khan and Khan 2012, P.157). A number of factors affect the EFL learners either positively or negatively, whereby, making them perceive English writing skills to be usually a challenging process beyond their cognitive abilities (Al Alami 2013, P.138). Hoever, Al Fadda (2012) points out that academic writing is a product of an individual's mind and so it is considered to be a mental and cognitive activity which can be difficult and challenge for many EFL students. According to Alfaki (2015), learners experience many difficulties while making attempts to write in a second/foreign language. Since writing is considered to be a challenging and a tiring activity which normally requires time for reflection and revision (Kavaliauskiene, 2010), it needs a lot of regular practice in semantic and syntactic features to produce a creative piece of work.

Hameed (2016) reveals that the findings from their pilot studies indicate that the students entering university education in Saudi Arabia have low proficiency levels in English (p.2). She opines that due to the poor proficiency levels in writing skills, students lose out valuable academic years because they make repeated attempts to complete the undergraduate programme, which, inturn results in stress and demotivation. Further, the tendency of language teacher to highlight errors with red annotation marks adds to their anxiety and frustration and so EFL teacher should focus on correcting those errors which cause most difficulty to the students (Al-Gharabally 2015, P.44). Therefore, Lee, Sedhu and Choy $(2015: 2)$ are of the opinion that EFL teachers have to be actively involved in facilitating the intended writing activity in the less stressful environment to the students, 
who, in turn, can demonstrate this intent through their actions during the given writing activity. They point out that the intent and perceptions of the students will also determine the level of motivation and willingness to make efforts to try and master the given writing activities for a successful outcome (P.2). Writing activities introduced in EFL clasrooms can range from highly controlled to free exercises wherein students copy from the board, record new material, write homework/tests and perform grammar exercise/s (Bukta, 2013). "Writing is one of the most difficult skills that language learners are expected to acquire, requiring the mastery of a variety of linguistic, cognitive, and sociocultural competencies." (Barkaoui, 2007, P.1). EFL undergraduates might find it difficult to cope with language learning tasks and activities which are beyond their comprehension levels. According to Roberton (2011:6), English language learner pedagogies often rely on language workbooks which frame learning through direct instruction. Due to lack of the adequate language proficiency, students may not be able to comprehend the grammar rules presented in the course materials, and therefore, the writing exercises that needs to be completed based on a direct instruction can increase the affective filter in the EFL undergraduates. Krashen (1982) points out that anxiety, motivation, and self-confidence are the three factors that contribute to affective filter in language learners. Though many language learning approaches have been evolved to reduce the affective filter, it still remains a major cause for students' poor performance in writing skills. Moreover, the perceptions that EFL students carry on writing skills can affect their motivation and interest towards writing tasks and activities that they regularly encounter inside and outside the classroom. For these reasons, the researchers felt the necessity to explore the perceptions of EFL students.

\section{FACTORS AFFECTING WRITING SKILLS DEVELOPMENT}

There are many factors that are obstacles to the development of basic competence in writing skills of EFL undergraduates. Though EFL students consider translation as a useful strategy for translating L1 into L2, their limited lexicon in foreign language resorts them to depend on the dictionary for word to word translation (Hoch, n.d.). The literal translation can lead to incomprehensibility to the readers or the evaluators. Poor writing skills originate from two factors, namely, the teacher and the learner (Fareed et al., 2016). The outdated pedagogical practices in error correction methods without constructive feedback often demotivates the EFL learners. Lack of self-interest and other attitudinal barriers rooted within oneself due to the past failures in English writing skills might make the EFL learners nervous and thereby approach a writing task with certain negative presuppositions. Fareed et al., (2016, P.83) points out that negative approach towards their academic English language courses, transfer of L1 knowledge to L2, and lack of interaction between the teachers and the EFL undergraduates concerning the ways to improve writing skills are the obstacles in the development of writing skills. According to Quintero's (2008) writing is a complicated skill to be developed because students have to use their mental processes to construct sentence structures and so they have to be motivated to write on the topics that interest them with appropriate teacher feedback. The findings of the study conducted by Rico (2014, P.83) reveals that in an EFL context there are internal as well as external factors that cause difficulties to productive skills. Rico points out that the six factors that cause difficulties are: teacher's methodology, unwillingness to use the target language, lack of adequate knowledge, language transfer, insecurity and time allotment. Lee (2005, p.336) opines that difficulties in writing arise from cognitive as well as of affective aspects and EFL students at all levels undergo negative experiences from instruction and evaluation. Also, students' academic performance depends on the frequency of language use inside and outside their classroom as well as on their attitudes towards the language they learn (Mosha 2014, p. 67).

\section{RESEARCH QUESTIONS}

This study addresses the following research questions:

1) Are EFL students aware of their strengths and weakness in writing skills?

2) How do EFL students perceive the effectiveness of their classroom teaching-learning process to enhance their writing skills?

3) What are the common perceptions that either enhance or hinder the basic writing competence of EFL undergraduates?

4) What strategies do EFL students use to overcome their writing difficulties?

The above research questions are addressed based on the factual information obtained from the study conducted at Aljouf University, Saudi Arabia.

\section{FIELD STUDY}

Writing skills are necessary for EFL undergraduates to succeed in their academic career and so the researchers felt the need to explore the perceptions of EFL undergraduates' at different levels of undergraduate education.

\section{Participants}

Data for the current study was obtained from 52 male students pursuing arts and science undergraduate courses at Aljouf University. These students are currently studying English language courses at various levels. At the undergraduate level, these students are expected to have minimum proficiency in English language skills to participate in communicative and tasks-based activities. They are also expected to possess basic competence in English writing skills to pass their exams. Students were informed that their responses to the open-ended and closed-ended questions of self-assessment inventory are meant for research purposes only.

\section{Self-assessment Inventory on Writing Skills}

A 30-item self-assessment inventory was administered to explore students' self-perceptions in their writing abilities. 
A self-assessment inventory gives insights of one's awareness to strengths and weaknesses of one's abilities in a particular area. A self-assessment of students' competency levels in basic English language writing skills is useful for making the teaching-learning process more productive. Students are expected to read the given statements in the self-inventory and circle an appropriate option which best describes their perceptions.

\section{LIMITATIONS OF THE STUDY}

This study is limited in the following ways:

1. The focus was only on the competency levels of basic writing skills in an EFL context.

2. The self-evaluation inventory focused only on the EFL students' perceptions and did not cover the perceptions of English language teachers.

3. The self-assessment statements are constructed based on the researchers' observations in a particular EFL writing context.

4. The data of only 52 EFL male undergraduates are analysed and presented in this study.

\section{DATA ANALYSIS}

The data analysis presented in this section are based on the students' responses to the self-evaluation statements.

\section{Analysis of the Self-assessment Inventory}

The analysis of self-assessment inventory in the present study followed the procedure of Nalliveettil and Khaled (2016) data analysis formula in which they "added up the number of responses given for the scale Agree + the number of the responses given for the scale Strongly Agree = Total percentage" (P.267). They followed the same procedure for the statements - Disagree and Strongly Disagree but with an exception to the third scale - undecided. However, the Self-assessment inventory administered in the current study consisted of five scales namely:

\section{1- Strongly Disagree \\ 2- Disagree \\ 3- Undecided \\ 4- Agree \\ 5- Strongly Agree}

The current analysis also followed the procedure set by Nalliveettil and Khaled (2016:267) wherein those students who marked Disagree and Strongly Disagree are grouped under one category as having a different perception when compared to the students who marked Agree and Strongly Agree are considered to be agreeing with the self-assessment statements. Also, the data of those students who marked $U n$ decided are presented in percentages.

The graphs presented below gives an overview of the individual percentages of each of the scales. For the purpose of clarity, a set of 10 items are grouped together in a graphic form:

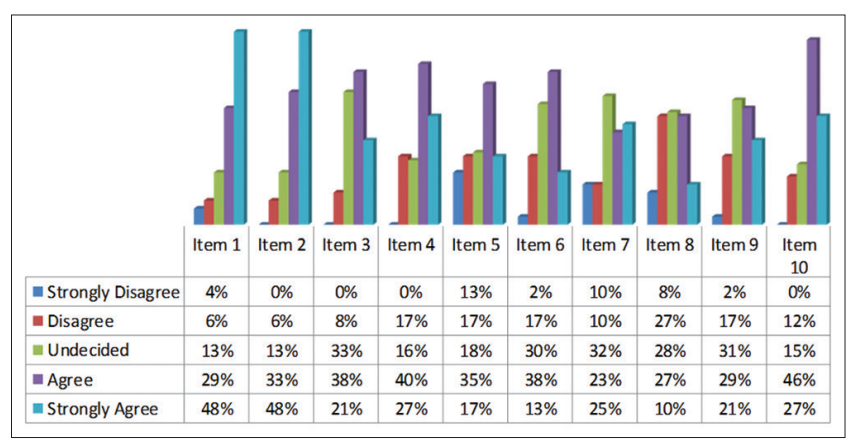

Graph 1. Analysis of Items - 1 to 10

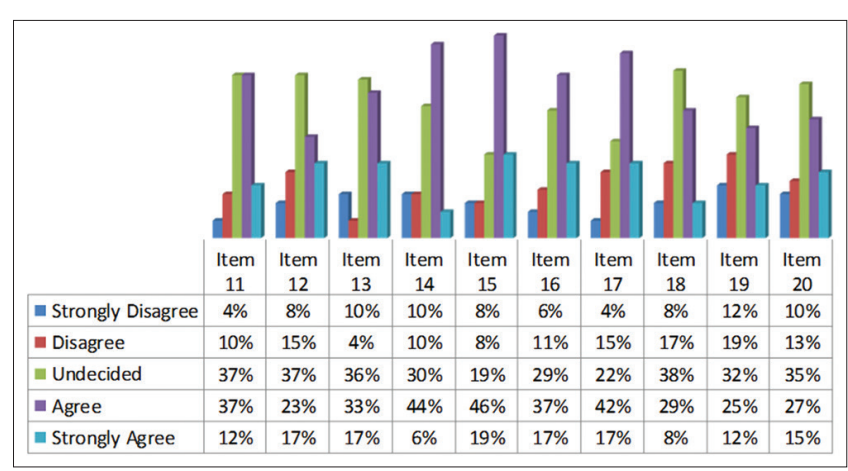

Graph 2. Analysis of Items - 11 to 20

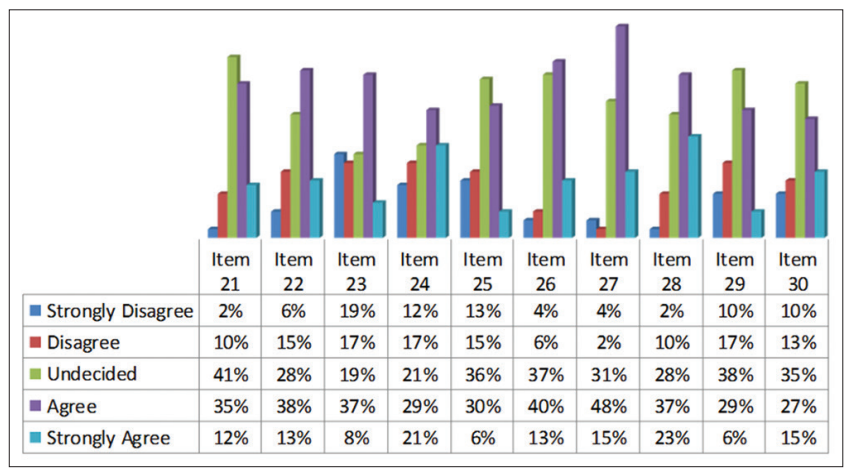

Graph 3. Analysis of Items - 21 to 30

\section{THE DATA ANALYSIS IS BASED ON THE FOLLOWING}

1. Motivational factors

2. Semantic and syntactic factors

3. Affective factors

4. Procedural factors

5. Library work

6. Assessment

7. Cognitive factors

8. Academic and non-academic factors

Each of the above factors is considered to be necessary for developing the basic competence in EFL students' writing skills.

\section{Motivational Factors}

The table below gives an overview of motivational factors that influence the writing skills of EFL undergraduates. 
Table 1. Motivational Factors

\begin{tabular}{|c|c|}
\hline Item No. & Self-evaluation statements \\
\hline 1. & $\begin{array}{l}\text { English writing skills are important for my } \\
\text { academic success }\end{array}$ \\
\hline 2. & $\begin{array}{l}\text { I am interested to improve my English writing } \\
\text { skills }\end{array}$ \\
\hline 3. & $\begin{array}{l}\text { I have to pass English language courses during } \\
\text { my university education }\end{array}$ \\
\hline 4. & $\begin{array}{l}\text { My English language course helps me improve } \\
\text { my written English }\end{array}$ \\
\hline 5. & $\begin{array}{l}\text { My English course books are very useful to } \\
\text { improve my English writing skills }\end{array}$ \\
\hline 6. & $\begin{array}{l}\text { I can understand the instructions given for a } \\
\text { writing task }\end{array}$ \\
\hline 7. & $\begin{array}{l}\text { My English teachers help me to understand what } \\
\text { is expected to be done for a given writing activity }\end{array}$ \\
\hline 8. & The spellings of English words are easy to learn \\
\hline
\end{tabular}

The percentages of each of the above items are presented in graphic form.

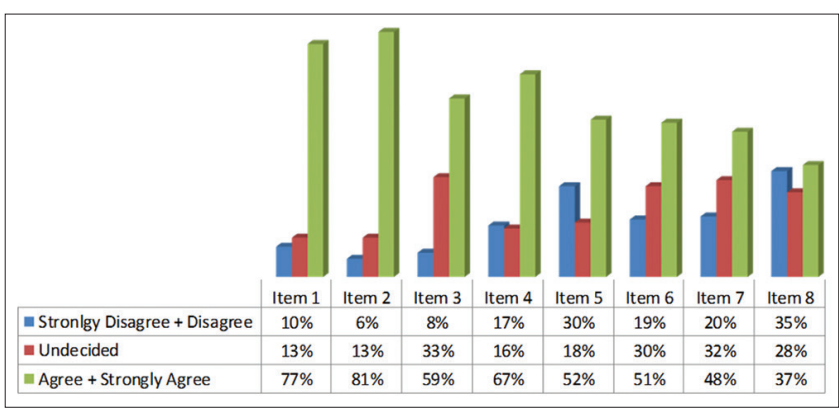

Graph 4. Analysis of Items - 1 to 8

The data analysis from the above graphic representations reveals that most of the students agree that English writing skills are essential for academic success and are interested in improving their English writing skills because it is a requirement for obtaining their graduate certification. A majority of students are of the opinion that their English courses help them to improve their written English. However, there are also students who either disagree or not sure of the effectiveness of their prescribed course books in improving their writing skills and find the instructions given in writing tasks difficult to comprehend. Also, most of the students seem to find English spellings difficult to learn and need more help from the English teachers to understand what is expected of them from a given writing activity.

\section{Semantic and Syntactic Factors}

The table below gives an overview of semantic and syntactic factors that influence the writing skills of EFL undergraduates.

Table 2. Semantic and syntactic factors

\begin{tabular}{ll}
\hline Item No. & Self-evaluation statements \\
\hline 9. & $\begin{array}{l}\text { When I do not know the spelling of any given } \\
\text { word, I refer to a dictionary }\end{array}$
\end{tabular}

10.

11.

While writing a sentence, I can arrange the words in an appropriate grammatical sequence

The percentages of each of the above items are presented in graphic form.

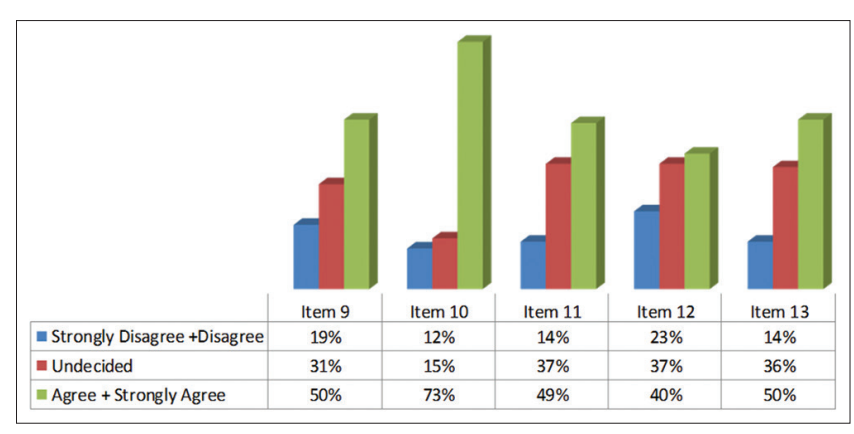

Graph 5. Analysis of Items - 9 to 12

The data analysis of the above graphic representation indicates that most of the learners try to remember the spelling of the English word as they learn it. A higher percentage of students seems to be unaware of their writing strategies like referring to a dictionary for spell check and use of punctuation marks. Also, when we combine the percentages of students disagreeing and undecided, it is found to be higher in the category related to the competency levels of sentence construction and arranging words in grammatical order to make meaningful sentences.

\section{Affective Factor}

The table below gives an overview of semantic and syntactic factors that influence the writing skills of EFL undergraduates.

Table 3. Semantic and syntactic factors

\section{Item No. Self-evaluation statement}

\begin{tabular}{ll}
\hline 14. I am nervous about making mistakes while writing \\
English words and sentences
\end{tabular}

The percentages of the above item are presented in graphic form.

The data analysis of the above graphic representation indicates that most of the students are nervous of making mistakes while writing English words and sentences. Also, a higher percentage of students seems to be not conscious of their grammatical errors while writing English words and sentences. 


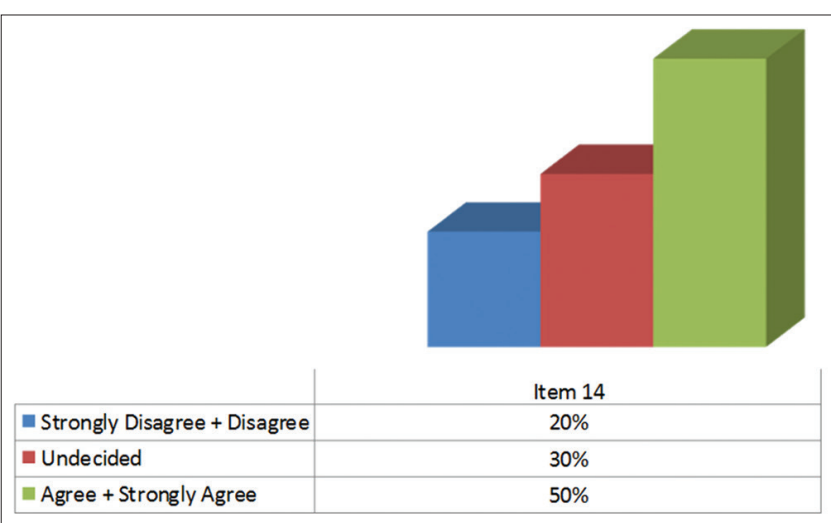

Graph 6. Analysis of Item No. 14

\section{Instructional Factors}

The table below gives an overview of the instructional factors that influence the writing skills of EFL undergraduates.

Table 4. Instructional factors

\begin{tabular}{ll}
\hline Item No. & Self-evaluation statements \\
\hline 15. & $\begin{array}{l}\text { I have a notebook to write important points during } \\
\text { the regular classroom sessions }\end{array}$ \\
16. & $\begin{array}{l}\text { I need help from my English teachers to complete } \\
\text { a given writing activity }\end{array}$ \\
17. & $\begin{array}{l}\text { I can understand the instructions given for a } \\
\text { writing task }\end{array}$ \\
18. & $\begin{array}{l}\text { I maintain a notebook to write the spellings of } \\
\text { unfamiliar words }\end{array}$ \\
\hline
\end{tabular}

The percentages of each of the above items are presented in graphic form.

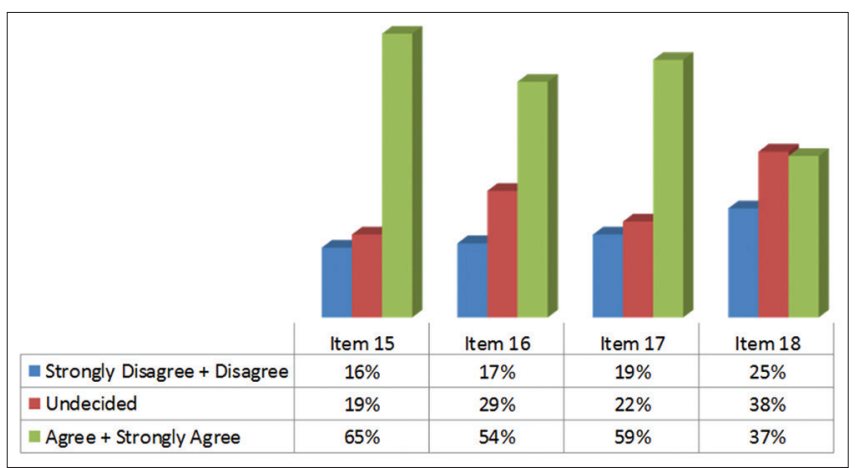

Graph 7. Analysis of Items - 15 to 18

The data analysis of the above graphic representation indicates that students write important points in their notebook and expect their English teachers to guide them to complete a given writing activity. The analysis also indicates that a higher percentage of students do not maintain a notebook to write the spellings of unfamiliar words. Also, there are students who seem to remain passive without seeking the guidance of their English teachers when they do not understand the given instructions for a writing activity.

\section{Library Work}

The table below gives an overview of the library work that influences the writing skills of EFL undergraduates.

Table 5. The effect of library work on the writing skills

\begin{tabular}{ll}
\hline Item No. & Self-evaluation statements \\
\hline 19. & $\begin{array}{l}\text { At home, I do a lot of practice in English writing } \\
\text { skills }\end{array}$ \\
20. & $\begin{array}{l}\text { My English teachers give writing homework at } \\
\text { least once a week }\end{array}$ \\
\hline
\end{tabular}

The percentages of each of the above items are presented in graphic form.

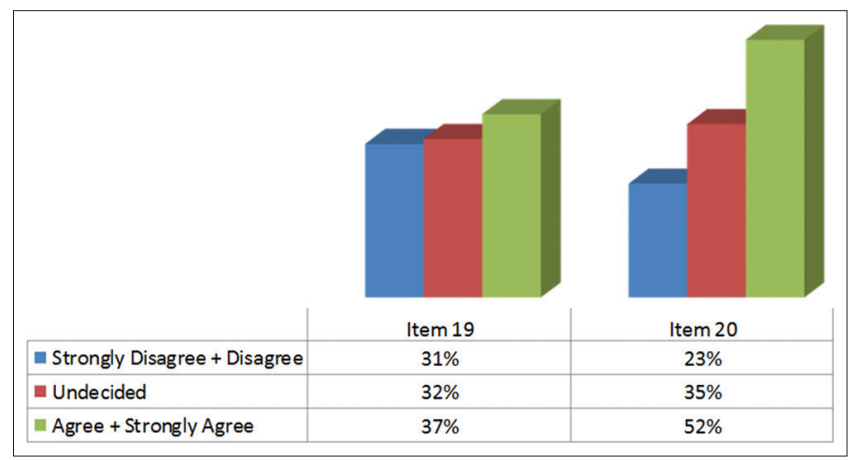

Graph 8. Analysis of Items - 19 to 20

The data analysis of the above graphic representation indicates that a higher percentage of students seems to be unaware of the necessity to practice English writing skills at home and there are also students who reveal that they are not aware of any assigned writing activities.

\section{Assessment}

The table below gives an overview of the assessment work that influences the writing skills of EFL undergraduates.

Table 6. The effect of assessment work on writing skills

\begin{tabular}{ll}
\hline Item No. & Self-evaluation statements \\
\hline 21. & I am aware of the errors I make in written English \\
22. & $\begin{array}{l}\text { My English teachers give feedback to improve } \\
\text { my writing skills }\end{array}$ \\
23. & $\begin{array}{l}\text { I have problems with English spellings and } \\
\text { sentences while writing exams in English }\end{array}$ \\
\hline
\end{tabular}

The percentages of each of the above items are presented in graphic form.

The data analysis of the above graphic representation indicates that a higher percentage seems to be unaware of the type of errors they make in written English. A higher percentage of students also agree that they do have problems with English spellings and sentences while writing exams in English. Most of the students agree that their English teachers give feedback to improve the writing skills. 


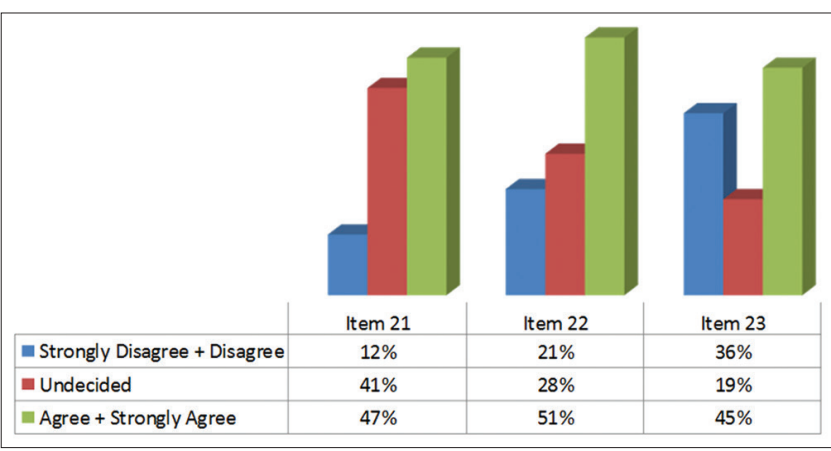

Graph 9. Analysis of Items - 21 to 23

\section{Cognitive Factors}

The table below gives an overview of the cognitive factors that influence the writing skills of EFL undergraduates.

Table 7. Cognitive factors

\begin{tabular}{ll}
\hline Item No. & Self-evaluation statements \\
\hline 24. & $\begin{array}{l}\text { When I start writing, I think in Arabic and then I } \\
\text { translate the words and sentences into English }\end{array}$ \\
25. & $\begin{array}{l}\text { I am not able to write English spellings and } \\
\text { sentences correctly because I do not have enough } \\
\text { exposure to English language }\end{array}$ \\
\hline
\end{tabular}

The percentages of each of the above items are presented in graphic form

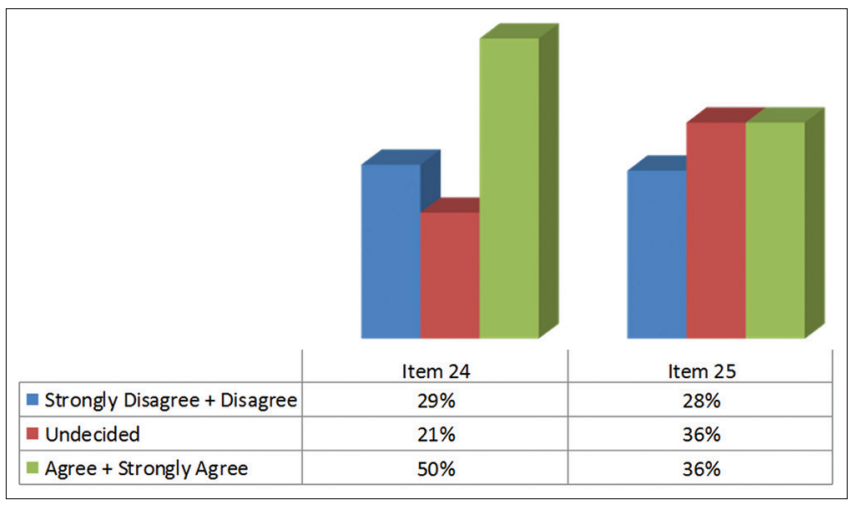

Graph 10. Analysis of Items - 24 to 25

The data analysis of the above graphic representation indicates that during the writing process, a higher percentage of students organize their ideas initially in Arabic and then translate them to English. There are also students who are not able to write English spellings and sentences correctly probably because of less use of English language in everyday communication.

\section{Academic and Non-academic Factors}

The table below gives an overview of the academic and non-academic factors that influence the writing skills of EFL undergraduates.

The percentages of each of the above items are presented in graphic form
Table 8. Academic and non-academic factors

\begin{tabular}{ll}
\hline 21. & I have to improve my English writing skills for \\
academic success \\
22. \\
I can get a good job if I improve my writing skills \\
in English \\
I can improve my writing skills if I practice \\
grammar exercises regularly \\
24. \\
I can improve my English writing skills without \\
anyone's help \\
My university is the best place where I can \\
improve my English writing skills
\end{tabular}

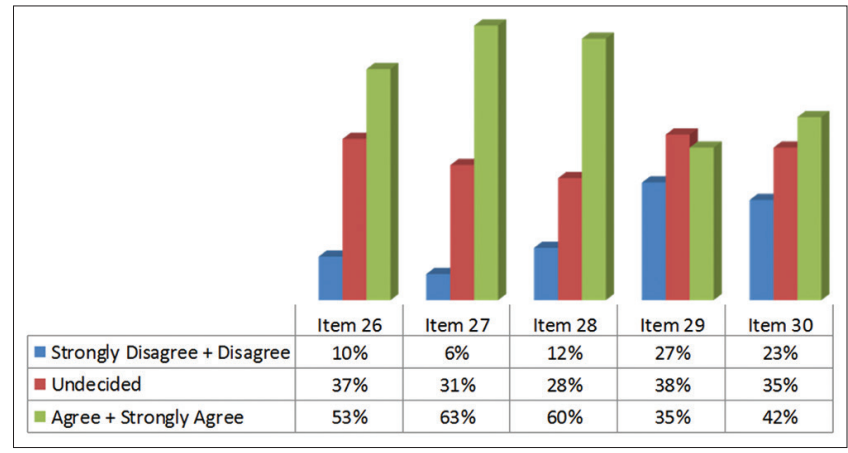

Graph 11. Analysis of Items - 26 to 30

The data analysis of the above graphic representation indicates that most of the students are aware that they have to improve their English writing skills for academic success and to get a good job. These students are also aware they have to practice grammar exercises regularly but seems to be not sure as to how they can improve their writing skills.

\section{DISCUSSION OF THE FINDINGS}

\section{Are EFL Students Aware of Their strengths and Weakness in Writing Skills?}

The findings of the study reveal that students have a positive perception regarding the need to improve their writing skills. Despite their positive perceptions, these EFL students are not aware of the strategies that would guide them towards adequate proficiency in writing skills. Also, the nervousness of making errors while writing English words and sentences can be a demotivating factor while learning a foreign language like English. The results of this study coincide with the findings of Westwood (2004) that many learners lack the motivation to actively participate in the writing tasks because of unsatisfactory results and achievements. However, the data analysis indicates that EFL students write important points during the classroom sessions. The findings of the current study also revealed that these EFL undergraduates, though nervous, are attentive during the teaching-learning process. The coursebook prescribed for undergraduates functions like a text-workbook, paving the way for the students to fill the empty spaces with words/sentences/ paragraphs under each guided writing activity. Teachers also can give immediate feedback on the language errors that need immediate attention. Students also reveal that they are not conscious of the grammatical errors while writing English words 
and sentences. Also, teachers need to understand the reasons behind grammatical errors that gets into the way of students language learning progression. Teachers can categorize the errors under various rubrics and give more practice in the areas where students lack the required language input for attaining proficiency in writing skills. At the pre-writing stage, teachers need to make the students aware of the writing rubrics through which their work will be judged. Students should be given opportunities to determine the evaluation criteria for a piece of writing. Through their involvement, EFL students can be made aware of the various language elements needed to produce accurate sentences and meaningful paragraphs.

\section{What are the Common Perceptions that Either Enhance or Hinder the Basic Writing Competence of EFL Undergraduates?}

Most of the EFL students reveal that they do make errors while writing English words. The findings of our study coincide with the observations of Alfaki (2015) that while attempting to write in a second language, learners do experience many difficulties. Though many studies are carried out in the field, mother tongue influence seems to be a major factor which remains challenging and needs to be addressed. In spite of the efforts of EFL teachers to improve the phonic skills through oral drills, the confusion in sound-letter combinations often leads to spelling errors. The attitude of students to consider writing as an academic requirement to pass English language courses rather than a means of communication to connect with non-native speakers remains as hindrance in EFL contexts. In the absence of everyday use, the language input which students receive during classroom hours remain either passive or even might be erased from the memory. EFL teachers need to realize that it is not enough that students be given input in vocabulary or grammar exercises but also be made aware of other features as well. This includes the format, length, style, purpose, tone, voice or other relevant features that make a piece of writing relevant and appropriate to a given context. However, students focus more on the answer keys for the given writing tasks or exercises and give less importance to learning the spelling, grammar rules, meaning or the application of the task in other similar contexts. Though the tasks and exercises in writing skills given in the prescribed course books are focused on specific situations and outcomes, a mismatch in the proficiency levels and the expectations of writing tasks makes it challenging for EFL undergraduates. Students find memorization of answer keys as a means to success in their exams. However, EFL teachers have to introduce writing activities that stimulate students' interest and participation, whereby they progress from basic to advanced writing skills.

\section{How do EFL Students Perceive the Effectiveness of Their Classroom Teaching-Learning Process to Enhance their Writing Skills?}

The findings of our study reveal that majority of the undergraduates agree that writing skills are essential for academic success and their extrinsic motivation towards obtaining a graduate certification makes them realize the necessity to improve English writing skills for career growth. Most of the students reveal that their English courses help them to improve their written English. These perceptions of the EFL students reveals the optimism they have towards the university education. However, the findings also indicate that there are students who do not approach their teachers when the instructions for a given writing activity is not clear to them. An absence of interaction can further aggravate the learning gaps and students remain fossilized without any improvements in their proficiency levels. EFL teachers need to address these gaps by reducing the affective filter that remains as obstacles in the writing skills development of undergraduates. Our findings coincide with Al Alami (2013:138) observations that EFL learners perceive English writing skills to be a challenging process and beyond their cognitive abilities. These perceptions can remain as impediments to achieving success in writing skills. Too much reliance on classroom writing instruction as a source of input, though reliable, can be supplemented with the latest available online e-learning platforms such as Blackboard Learn. Many universities have introduced e-learning platforms to improve the quality of instruction and enhance teacher-student interaction during off-campus periods. Teachers can assign guided writing activities based on the proficiency levels of undergraduates while students can access available online vocabulary and grammar resources to enhance their proficiency levels in writing skills. When EFL students regularly participate in the assigned writing activities, it can be a source of language input, whereby, students can progress from basic to advanced writing skills.

\section{What Strategies Do EFL Students use to Overcome their Writing Difficulties?}

The findings of our study reveal that students make efforts to use translation as a strategy to create language expressions for a given writing task. The variations in syntactic rules of Arabic and English can make their translations redundant or ungrammatical. A frequent use of translation strategies can be a hindrance to the development of writing skills. In order to quickly progress in everyday classroom writing activities, teachers might also encourage students to rely on translation strategies. Rushing through writing activities without adequate focus on cognitive and affective factors of EFL undergraduates can hinder the progress of writing skills development. Due to L1 interference, students often make errors while writing spellings and so the EFL teachers need to incorporate dictionary skills instruction to overcome the orthographical obstacles. Through dictionary skills instruction, undergraduates can overcome vocabulary deficiencies as well as confusions in the use of homophones. Another challenging area that needs immediate attention is the subject-verb agreement. EFL students are habituated to think in their mother tongue and try to translate their thoughts from Arabic to English. However, spontaneous construction of simple sentence structures from Arabic to English is quite challenging for the EFL undergraduates. While these stu- 
dents struggle to translate the first language into a foreign language, the demands of course curriculum expect them to produce creative language structures. Often, EFL teachers consider these expectations of course curriculum to be primary and tend to ignore the basic aspects of writing skills that need immediate attention. The resulting outcome being poor pedagogical practices is an obstacle to the development of writing strategies in EFL classrooms. In order to overcome these poor pedagogical practices, EFL teachers need to be given more training on the ways to improve the writing strategy instruction. Teachers can also make use of the available web resources and tailor it to the needs of the classroom. However, a careful analysis of the appropriateness and relatedness of the instructional materials to the prescribed course curriculum is necessary to make it resourceful and productive. EFL teachers can guide the students to a writing task by providing a writing checklist, specifying different aspects that have to be considered for producing a creative piece of work. The findings of our study also revealed that EFL undergraduates are unable to progress in their writing skills because they are confined to the use of translation and therefore need more exposure to vocabulary input as well as grammatical competence. Task-based writing activities which are currently followed in EFL classrooms, though student-centred, often poses difficulty to undergraduates because it tests their creativity in the use of higher-order syntactic structures. EFL students should be able to differentiate academic writing from non-academic and also be trained to present the content in an appropriate language that is relevant to a particular type of audience.

\section{CONCLUSION AND RECOMMENDATIONS}

The present study focused on addressing specific issues related to writing skills in EFL context. The findings reveal that students perceive classroom writing instruction as an important factor for their academic growth. Most of the EFL undergraduates are aware that writing skills are necessary for their career development. Since English is a subject of the study at different levels of EFL undergraduate education, there needs to be a broader understanding of how other language skills are integrated into the prescribed course materials. Further research needs to be carried out to elicit the views of EFL teachers on the effectiveness of writing skills instruction. A focused study on EFL undergraduates' test scores at different periods of a semester can give useful insights of their proficiency levels in writing skills. Since a semester is a limited duration of time, research can also be carried on the task-based activities that students are given exposure to during a semester. In order to provide writing strategy instruction, EFL teachers need to be conscious of students' proficiency levels as well as an awareness to different genres of writing.

\section{REFERENCES}

Abraham, A. P. (2015). Teaching and Learning to Write: Using a Task-Based Approach in an EFL class (V. S. Thakur \& A. Roscoe, Eds.). In A. Rahma (Ed.), Meth- odologies for Effective Writing Instruction in EFL and ESL Classrooms (pp. 115-130). Hershey PA: Information Science Reference.

Al Alami, S. E. (2013). Enhancing Writing Skills within EFL University Contexts: Case Study in the United Arab Emirates. Arab World English Journal, 5, 1, 137-150.

Al Fadda, H. (2012). Difficulties in Academic Writing: From the Perspective of King Saud University Postgraduate Students. English Language Teaching, 5(3), 123-130.

Al-Gharabally, M. (2015). The Writing Difficulties Faced by L2 Learners and how to Minimize Them. International Journal of English Language and Linguistics Research, $3(5), 42-49$.

Alfaki, I. M. (2015). University Students' English Writing Problems: Diagnosis and Remedy. International Journal of English Language Teaching, 3(3), 40-52.

Almubark, A. A. (2016). Exploring the Problems Faced by the Teachers in Developing English Writing Skills for the Students in Saudi Arabia. International Journal of English Language Teaching, 4(10), 10-23.

Barkaoui, K. (2007). Teaching Writing to Second Language Learners: Insights from Theory and Research. TESL Reporter, 40(1), 35-48. Retrieved from https:// journals.lib.byu.edu/spc/index.php/TESL/article/viewFile/32304/30503.

Bukta, K. (2013). Rating EFL written performance. London: Versita.

Cai, L. J. (2013). Students' Perceptions of Academic Writing:. Language Education in Asia, 4(1), 5-22.

Craig, J. L. (2013). Integrating writing strategies in EFL/ ESL university contexts: A writing-across-the-curriculum approach. New York: Routledge.

Deshpande, S. (2014). Teaching Writing Skills in English: Involvement of Students in the Assessment and Correction of their Errors. International Journal of English Language Teaching, 3(1), 68-73.

Hameed, P. F. M (2016). Assessing the Academic Writing Proficiency of EFL Learners at Qassim University: Honing the Skills of Young Writers. British Journal of English Linguistics, 4(4), 1-11.

Hoch, F. (n.d.). Writing and English as a Second Language Strategies for helping English Language Learners throughout the writing process. Retrieved May 22, 2017, from http://www.learnnc.org/lp/pages/672?ref=search

Kavaliauskiene, G. (2010). Skills of Reading, Writing and Translating in English For Specific Purposes. The Buckingham Journal of Language and Linguistics,3, 11-23. Retrieved May 22, 2017.

Khan, M.O \& Khan, I.A. (2012). A Study of the Difficulties and Possible Remedies of the Writing Skill among the Students of Preparatory Year, Najran University: TEFL in the Context. Language in India, 12 (1930 2940), 152-175.

Krashen, S. D. (1982). Principles and Practice in Second Language Acquisition. Retrieved May 15, 2017, from http://www.sdkrashen.com/content/books/principles and_practice.pdf

Kroll, B. (Ed.). (1990). Second Language Writing: Research 
Insights for the Classroom. New York, United States of America: Cambridge University Press.

Lamtara, S. (2016). New Technology and the Process Based Approach to Writing. Arab World English Journal, 3(CALL), 155-168. Retrieved March 11, 2017, from http://www.awej.org/index.php?option=com content\&view=article\&id=959: sana-lamtara\&catid=67:special-issue-on-call-july-2016\&Itemid $=138$

Lee, Sy-ying. (2005). Facilitating and Inhibiting Factors in English as a Foreign Language Writing Performance: A Model Testing With Structural Equation Modeling. Language Learning, 55:2, 335-374.

Mohite, M. (2014). An Investigation into the English Language Writing Strategies Used by Polish EFL Secondary School Learners (MA TESOL dissertation, London Metropolitan University) (p. 11). British Council.

Mosha, M.A (2014). Factors Affecting Students' Performance in English Language in Zanzibar Rural and Urban Secondary School. Journal of Education and Practice. 5, 35, 64-76.

Myles, J. (2002). Second Language Writing and Research: The Writing Process and Error Analysis in Student Texts. TESL-EJ, 6(2), a-1. Retrieved March 10, 2017, from http://tesl-ej.org/ej22/a1.html

Nalliveettil, G. M., \& Khaled, T. H., Alenazi. (2016). The Impact of Mobile Phones on English Language Learn- ing: Perceptions of EFL Undergraduates. Journal of Language Teaching and Research, 7(2), 264-272.

Rico, L.J.A. (2014). Identifying Factors Causing Difficulties to Productive Skills Among Foreign Languages Learners. Open. Writ. Doors. J. 11, 1, 65-86.

Roberton, T. (2011). Reducing Affective Filter In Adult English Language Learning Classrooms (Unpublished master's thesis). The Evergreen State College. doi: http://archives.evergreen.edu/masterstheses/Accession2010-03MEd/2011/Roberton_Tim_MEd_2011. pdf

Sedhu, D. S., Choy, S. C., \& Lee, M. Y. (2015). Students' Perceptions of Using Collaborative Learning as a. American Journal of Applied Psychology, 4(3-1), 1-6.

Westwood, P. (2004). Learning and Learning Difficulties: Approaches to Teaching and Assessment. London: David Fulton

Zoheb, H and Taj Mohammad (2016). Difficulties of learning EFL in KSA: Writing skills in context. International Journal of English Linguistics, 6, (3), Canadian Center of Science and Education.

Fareed, M., A., Ashraf, \& M., Bilal. (2016). ESL Learners' Writing Skills: Problems, Factors and Suggestions. Journal of Education and Social Sciences,4(2): 1, 81-92.

Quntero. (2008).Blogging: A way to foster EFL writing,Colomb. Appl. Linguist. J. 10: 7- 49, 2008 